\title{
Low-Density Lipoprotein Receptor-Related Protein 5
}

National Cancer Institute

\section{Source}

National Cancer Institute. Low-Density Lipoprotein Receptor-Related Protein 5. NCI

Thesaurus. Code 195414.

Low-density lipoprotein receptor-related protein 5 (1615 aa, 179 kDa) is encoded by the human LRP5 gene. This protein is involved in ligand binding, endocytosis and downstream Wnt signaling. 